\title{
Nasolacrimal Duct Malignancy or IgG4- Related Disease? A Curious Case Report of a Nasal Vestibular Mass and Review of the Literature
}

\author{
Nazolakrimal Kanal Malignitesi mi yoksa IgG4 ile Ilgili Bir Hastalık mı? \\ Nazal Vestibül Kitlesinin Illginç Bir Vaka Sunumu ve Literatürün Gözden \\ Geçirilmesi
}

\section{Veejie KHOO ๑, Hillary Shu Jiun KHOO ๑, Liang Chye GOH ๑}

Ethics Committee Approval: Not Applicable.

Conflict of Interest: The authors declare that they have no competing interest.

Funding: None.

Informed Consent: Was taken.
Cite as: Khoo V, Khoo HSJ, Goh LC. Nasolacrimal duct malignancy or IgG4- related disease? A curious case report of a nasal vestibular mass and review of the literature. Medeni Med J. 2021;36:281-6.

\begin{abstract}
IgG4-related disease (IgG4-RD) is a fibro-inflammatory condition associated with tumefactive lesions at multiple sites. IgG4-RD was initially recognized in 2001 in a case of autoimmune pancreatitis. However, the disease was not limited to the pancreas but involved other organs such as the bile ducts, lacrimal glands, lymph nodes and salivary glands. IgG4-RD is rarely seen with an estimated incidence of 0.2 to $1 / 100.000$ as reported in Japan, but with minimal to no incidence data have been published in Western countries. We hereby report a case of an IgG4related mass arising from the nasolacrimal duct, masquerading as a sinonasal mass.

Keywords: IgG4-related disease, nasal mass, nasolacrimal mass

öz

IgG4 ile ilișkili hastalık (IgG4-RD), birçok bölgede tümefaktif lezyonlarla ilișkili fibro-inflamatuar bir durumdur. IgG4-RD ilkin 2001 yilında bir otoimmün pankreatit vakasında görüldü. Ancak hastalık pancreas ile sınırlı olmayıp safra kanalları, gözyașı bezleri, lenf dügüüleri ve tükürük bezleri gibi diğer organları da kapsıyordu. IgG4-RD nadirdi, Japonya'da rapor edilen tahmini insidans 0,2 ila 1/100,000 iken, Batı ülkelerinde minimal veya hiçbir insidans verisi yoktu. Burada, nazolakrimal kanaldan kaynaklanan ve sinonazal bir kitle olarak maskelenen bir IgG4 ile ilişkili kitle olgusu sunuyoruz.
\end{abstract}

Anahtar kelimeler: IgG4 ile ilişkili hastalık, nazal kitle, nazolakrimal kitle
Received: 26 June 2021

Accepted: 17 August 2021

Online First: 30 September 2021

Corresponding Author:

V. Khoo

ORCID: 0000-0002-9475-1475

Hospital Sultanah Aminah, Department of Otorhinolaryngology,

Johor Bahru, Malaysia

v veejie7352@gmail.com

H.S.J. Khoo

ORCID: 0000-0002-5666-4557

L.C. Goh

ORCID: 0000-0002-3059-7253

Hospital Sultanah Aminah, Department of Otorhinolaryngology, Johor Bahru, Malaysia 


\section{INTRODUCTION}

IgG4-related disease (IgG4-RD) is a fibroinflammatory condition associated with tumefactive lesions at multiple sites ${ }^{1}$. Hamano et al. $^{2}$ first discovered IgG4-RD in 2001 by showing correlation between elevated serum IgG4 levels and chronic inflammatory lesions in the pancreas leading to autoimmune pancreatitis ${ }^{1}$. This disease is not limited to the pancreas but also involves bile ducts, lacrimal glands, lymph nodes, and salivary glands ${ }^{2}$. IgG4-RD is rarely seen disease with an estimated incidence of 0.2 to 1 per 100,000 population reported in Japan and minimal incidence data are available in Western countries ${ }^{2}$. We hereby report a case of IgG4-related mass arising from the nasolacrimal duct, masquerading as a sinonasal mass.

\section{CASE REPORT}

A 59-year-old lady presented to us with unprovoked epistaxis coming from her left nostril, associated with left sided nose block and whitish nasal discharge for six months. She denied headache, fever, and any constitutional symptoms. On examination, rigid nasal endoscopy showed a left -sided vascularized sinonasal mass (Figure 1), that was hard in consistency and completely obstructed the left nasal vestibule. Endoscopic assessment through the right nostril showed clear nasal cavity with normal nasopharynx. Her physical examination showed intact cranial nerves with no palpable cervical lymph nodes.

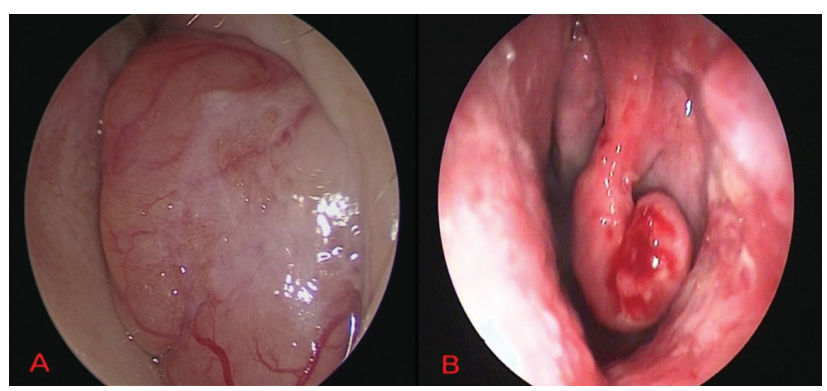

Figure 1. Image A representing the Endoscopic view of left vascularized sinonasal mass occupying the whole of left nasal vestibule. Image B representing the left nasal cavity after the mass was removed.
The clinical findings were suspicious of malignancy, therefore we proceeded with a computed tomography (CT) scan of the paranasal sinus, which showed a hypodense mass on the left anterior ethmoid sinus encasing the distal septum measuring (3.7 (AP) x $1.8(\mathrm{~W}) \times 2.4$ (CC) (Figure 2 ), with right maxillary sinus thickening and enlarged level $1 \mathrm{~b}$ cervical lymph node measuring $1.1 \mathrm{~cm}$, and well-pneumatized bilateral frontal, sphenoid and mastoid air cells. Biopsy of the mass showed increased number of non-malignant plasma cells (positive for CD138). This finding did not correlate with her clinical presentation and imaging findings. Then, we proceeded with examination under anaesthesia and left nasal mass was excised via endoscopic sinus surgery. We observed a left nasal mass arising from the lateral wall of the left nasal cavity, just anterior to the left middle turbinate, involving the anterior one-third of the left inferior turbinate. There was a visible stump arising from the lacrimal region of the lateral nasal wall and we proceeded with excision of the tumour. The mass was excised completely and sent for histopathological examination. The patient was then discharged in good health on the next day and she was started on regular alkaline nasal douching.

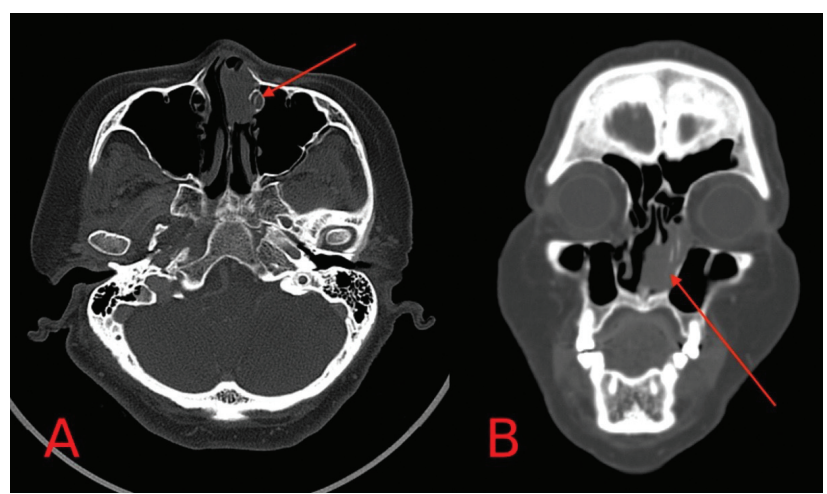

Figure 2. CT images of A-Axial view CT Paranasal sinus showing a left sided nasal mass. Note the posteromedial defect of the nasolacrimal duct. B-Coronal view of paranasal sinus, demonstrating a left nasal mass extending to the nasolacrimal duct.

The histopathological examination of the left nasal mass (Figure 3) showed fibro-inflammatory lesion that consisted of lymphohistiocytic infiltrates 
with background of vague storiform-like pattern fibrosis (highlighted by Mason trichrome stain), and the presence of emperipolesis (highlighted by immunohistochemical S100, CD 68 stains). Furthermore, her blood tests revealed raised serum IgG level of $2012 \mathrm{mg} / \mathrm{dL}$. Both histopathological findings and raised serum IgG level pointed towards the diagnosis of IgG4-RD. Computed tomgraphies of thorax, abdomen and pelvis did not show any other organ involvement. She was started on systemic therapy. At sixmonth follow up, there was no local recurrence on repeated nasal endoscopies (Figure 2) and she has achieved complete remission.

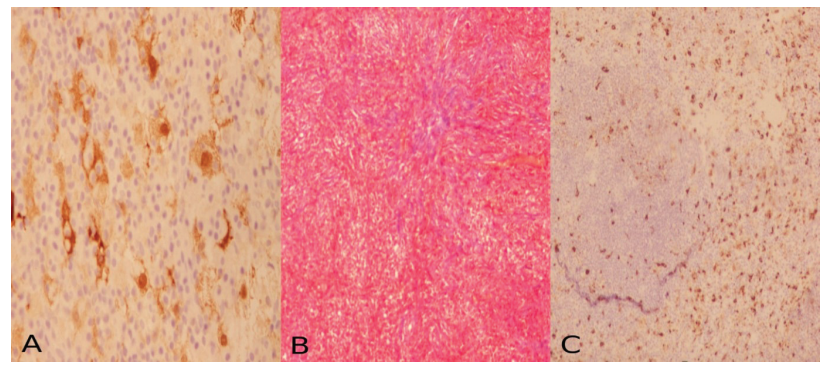

Figure 3. Histopathologic samples from tumour. Image A representing tissue with $\mathrm{CD} 68$. Image B representing tissue with Mason Trichome stain showing characteristic storiform pattern fibrosis. Image C representing S100 stain showing emperipolesis.

\section{DISCUSSION}

Our literature review involved search results of case reports obtained from PUBMED, Google Scholar, MEDLINE and EMBASE using the keywords "sinonasal", "nasal", "IgG4-related disease", and "paranasal sinus". Case reports of isolated sinonasal IgG4-RD were collected for the time interval between 2011 and 2021 prior to the completion of the current case report. In total, 15 case reports were identified and included in our summary (Table 1 ). In total, 11 male and five female cases have been reported within the past 10 years with an age range of 15 to 72 , with no noticeable bias towards age extremities. The mean age of presentation was 47 years with male preponderance while symptoms were highly nonspecific. Most cases were multicentric (involving more than one site in the sinonasal region) while the commonest sinus being affected by tumour was the maxillary sinus followed by the ethmoids and sphenoid sinuses. All reported cases had gone into remission after surgery and systemic immunosuppressant therapy.

IgG4-RD is a systemic chronic inflammatory disease characterized by relapsing-remitting episodes of tumour-like lesion formations in different sites of the body. It is caused by local tissue infiltration by lymphocytes and IgG4 secreting plasma cells which often respond well to systemic steroids ${ }^{3,4}$. The site of tumour formation varies from one individual to another and can occur either metachronously or synchronously. The commonest affected organs in the head and neck regions were the salivary and lacrimal glands ${ }^{3,5}$. Nomenclatures have been developed to represent IgG4-RD at certain parts of the head and neck regions namely Mikulicz's disease (lacrimal glands), Kuttner's disease (submandibular glands), and eosinophilic angiocentric fibrosis (upper respiratory tract and paranasal sinuses). However, eosinophilic angiocentric fibrosis was renamed as IgG4-RD in recent years ${ }^{4}$. Diagnosis is made based on a set of diagnostic criteria set by the Japanese IgG4 team created by the Ministry of Health, Labor and Welfare (MHLW) of Japan in 2011. Its diagnostic criteria include clinical features of tumour development in single or multiple organs, increased serum IgG4 (>135 mg/dL) levels, and characteristic histopathological features ${ }^{6}$.

Our case demonstrates a unique case of isolated nasal vestibular mass which was protruding from the nostril (Figure 2) with a highly vascularized appearance (Figure 1). This appearance gave a false impression of vascular lesion arising from the nasal cavity which may represent malignancy, granulomatous lesion like Wegener's granulomatosis or a benign vascular lesion like a haemangioma or angiofibroma. The most prudent step after clinical assessment is to perform 
Table 1. Review of the literature.

\begin{tabular}{|c|c|c|c|c|c|c|c|}
\hline No & Authors & Age & Gender & $\begin{array}{l}\text { Presenting } \\
\text { symptoms }\end{array}$ & $\begin{array}{l}\text { Nasal and paranasal } \\
\text { sinus involvement }\end{array}$ & Treatment & Outcome \\
\hline 1 & $\begin{array}{l}\text { Alt et al } \\
2012^{[12]}\end{array}$ & 38 & Female & Headache & B/L sphenoid & $\begin{array}{l}\text { Surgical debridement; } \\
\text { topical fluticasone }\end{array}$ & $\begin{array}{l}\text { Relapsed } \\
\text { after surgery } \\
\text { subsequently } \\
\text { on remission }\end{array}$ \\
\hline 2 & $\begin{array}{l}\text { Sasaki et al } \\
2012 \text { [13] }\end{array}$ & 71 & Male & $\begin{array}{l}\text { Nasal obstruction, } \\
\text { Right facial swelling }\end{array}$ & $\begin{array}{l}\text { B/L nasal cavity, maxillary } \\
\text { sinus. Left pterygopalati- } \\
\text { ne fossa }\end{array}$ & Prednisolone & Remission \\
\hline 3 & $\begin{array}{l}\text { Lindau et al } \\
2013^{[14]}\end{array}$ & 69 & Male & Right eye diplopia & $\begin{array}{l}\text { Right maxillary, ethmoid, } \\
\text { frontal sinus }\end{array}$ & $\begin{array}{l}\text { Prednisolone; surgical } \\
\text { debridement; } \\
\text { Rituximab }\end{array}$ & Remission \\
\hline 4 & $\begin{array}{l}\text { Cain et al } \\
2014^{[15]}\end{array}$ & 62 & Female & Epistaxis & Sphenoid sinus & Prednisolone & Remission \\
\hline 5 & $\begin{array}{l}\text { Morris et al } \\
2014^{[16]}\end{array}$ & 34 & Male & Nasal obstruction & Nasal septum & $\begin{array}{l}\text { Prednisolone; } \\
\text { methotrexate }\end{array}$ & Remission \\
\hline 6 & $\begin{array}{l}\text { Prabhu et al } \\
2014\end{array}$ & 15 & Female & $\begin{array}{l}\text { Nasal obstruction, } \\
\text { epistaxis }\end{array}$ & $\begin{array}{l}\text { Right maxillary sinus, } \\
\text { septum }\end{array}$ & Prednisolone & Remission \\
\hline 7 & $\begin{array}{l}\text { Prabhu et al } \\
2014^{[9]}\end{array}$ & 15 & Female & $\begin{array}{l}\text { Bloody rhinorrhoea, } \\
\text { facial swelling, trismus }\end{array}$ & $\begin{array}{l}\text { Right maxillary, ethmoid, } \\
\text { sphenoid sinus, septum }\end{array}$ & Prednisolone & Remission \\
\hline 8 & $\begin{array}{l}\text { Song et al } \\
2015\end{array}$ & 72 & Male & $\begin{array}{l}\text { Left eye proptosis, } \\
\text { periorbital pain, } \\
\text { post nasal drip }\end{array}$ & $\begin{array}{l}\text { Left maxillary, ethmoid } \\
\text { sinus, left orbit }\end{array}$ & $\begin{array}{l}\text { Surgical } \\
\text { debridement; } \\
\text { prednisolone }\end{array}$ & Remission \\
\hline 9 & $\begin{array}{l}\text { Kurien et al } \\
2015^{[18]}\end{array}$ & 21 & Male & $\begin{array}{l}\text { Facial pain, } \\
\text { headache, proptosis }\end{array}$ & $\begin{array}{l}\text { Maxillary sinus, pterygoid } \\
\text { plate, orbital floor }\end{array}$ & $\begin{array}{l}\text { Surgical } \\
\text { debridement; } \\
\text { prednisolone }\end{array}$ & Remission \\
\hline 10 & $\begin{array}{l}\text { Kojima et al } \\
2015^{[19]}\end{array}$ & 67 & Male & Nasal obstruction & $\begin{array}{l}\text { Maxillary, sphenoid, } \\
\text { frontal sinus, nasal } \\
\text { septum }\end{array}$ & Steroid therapy & Remission \\
\hline 11 & $\begin{array}{l}\text { Vandjelovic et al } \\
2015^{[20]}\end{array}$ & 46 & Male & $\begin{array}{l}\text { Epistaxis, facial } \\
\text { pain, rhinorrhoea }\end{array}$ & $\begin{array}{l}\text { Ethmoid sinus, frontal } \\
\text { recess }\end{array}$ & $\begin{array}{l}\text { Surgical } \\
\text { debridement; } \\
\text { prednisolone }\end{array}$ & Remission \\
\hline 12 & $\begin{array}{l}\text { Chen et al } \\
2016\end{array}$ & 36 & Male & $\begin{array}{l}\text { Nasal pain, } \\
\text { headache }\end{array}$ & $\begin{array}{l}\text { Ethmoid sinus, middle } \\
\text { turbinate }\end{array}$ & $\begin{array}{l}\text { Surgical } \\
\text { debridement; } \\
\text { prednisolone }\end{array}$ & Remission \\
\hline 13 & $\begin{array}{l}\text { Gontarz et al } \\
2016^{[22]}\end{array}$ & 30 & Male & $\begin{array}{l}\text { Spontaneous loss } \\
\text { of teeth, epistaxis }\end{array}$ & $\begin{array}{l}\text { Maxillary, ethmoid sinus, } \\
\text { upper alveolar mucosa }\end{array}$ & Steroid therapy & Remission \\
\hline 14 & $\begin{array}{l}\text { Bashyam et al } \\
2018^{[17]}\end{array}$ & 71 & Male & $\begin{array}{l}\text { Right cheek } \\
\text { swelling, mild } \\
\text { proptosis }\end{array}$ & $\begin{array}{l}\text { Right maxillary sinus, } \\
\text { nasal cavity, orbit }\end{array}$ & $\begin{array}{l}\text { Prednisolone; } \\
\text { mycophenolate }\end{array}$ & Remission \\
\hline 15 & $\begin{array}{l}\text { Kouwenberrg et al } \\
2019 \text { [1] }\end{array}$ & 48 & Male & $\begin{array}{l}\text { Spontaneous loss } \\
\text { of teeth, nasal pain, } \\
\text { headache }\end{array}$ & $\begin{array}{l}\text { Upper alveolar mucosa, } \\
\text { maxillary, ethmoid sinus }\end{array}$ & $\begin{array}{l}\text { Surgical } \\
\text { debridement; } \\
\text { prednisolone; } \\
\text { azathioprine }\end{array}$ & Remission \\
\hline
\end{tabular}


V. Khoo et al. Nasolacrimal Duct Malignancy or IgG4- Related Disease? A Curious Case Report of a Nasal Vestibular Mass and Review of the Literature

contrasted scan (MRI or CT scan) to assess the vascularity of the tumour, followed by biopsy of the tumour to identify the pathology. The treatment for this patient was consistent with the consensus of treatment for sinonasal tumour, which is surgical excision followed by long term treatment with systemic steroids ${ }^{7}$. The outcome of this case was like most of the literature, whereby the majority had gone into remission ${ }^{7}$.

Nasal manifestation of IgG4-RD is uncommon and may masquerade chronic sinusitis ${ }^{7,8}$. Often, patients can present with concurrent orbital manifestations and may be linked to Mikulicz disease when presenting with bilateral lesions ${ }^{9}$. Our case showed a lesion arising from the right nasolacrimal duct which enlarged and subsequently occupied the entire nasal vestibule without significant local invasion into the surrounding sinuses. Histopathological assessment was straightforward due to the characteristic features seen in the diagnostic criteria such as the storiform fibrosis and obliterative phlebitis ${ }^{5}$, but no specific histological evidence of the nasolacrimal duct was seen in our samples. When compared with other cases in the literature (Table 1), symptoms were often indistinguishable and nonspecific. Surprisingly, isolated unilateral nasolacrimal duct lesions tend to grow without extensive local bony destruction compared to bilateral diseases ${ }^{10}$ which suggests that unilateral involvement may have better prognosis in sinonasal IgG4-RD.

\section{CONCLUSION}

This case report highlighted a rare case of IgG4$\mathrm{RD}$ arising from the nasolacrimal duct and its behavior in comparison to the literature. We have showed that nasolacrimal duct tumours tend to be less locally invasive as they grew towards the nasal cavity at their early stages and respond well to systemic steroids after endoscopic excision.

\section{REFERENCES}

1. Kouwenberg WL, Dieleman FJ, Willems SM, Rosenberg AJWP. Inflammatory pseudotumour of the alveolar process of the maxilla as clinical manifestation of IgG4related disease: a case report and literature review. Int J Oral Maxillofac Surg. 2020;49:722-5. [CrossRef]

2. Palazzo E, Palazzo C, Palazzo M. IgG4-related disease. Joint Bone Spine. 2014;81:27-31. [CrossRef]

3. Wallace ZS, Deshpande V, Mattoo H, et al. IgG4-related disease: clinical and laboratory features in one hundred twenty-five patients. Arthritis Rheumatol. 2015;67:246675. [CrossRef]

4. Stone JH, Khosroshahi A, Deshpande V, et al. Recommendations for the nomenclature of IgG4-related disease and its individual organ system manifestations. Arthritis Rheum. 2012;64:3061-7. [CrossRef]

5. Al-Khalili OM, Erickson AR. IgG-4 related disease: an introduction. Mo Med. 2018;115:253-6. PMID: 30228732.

6. Umehara H, Okazaki K, Nakamura T, et al. Current approach to the diagnosis of IgG4-related disease Combination of comprehensive diagnostic and organspecific criteria. Mod Rheumatol. 2017;27:381-91. [CrossRef]

7. Song BH, Baiyee D, Liang J. A rare and emerging entity: Sinonasal IgG4-related sclerosing disease. Allergy Rhinol (Providence). 2015;6:151-7. [CrossRef]

8. Moteki H, Yasuo M, Hamano H, Uehara T, Usami S. IgG4related chronic rhinosinusitis: a new clinical entity of nasal disease. Acta Otolaryngol. 2011;131:518-26. [CrossRef]

9. Prabhu SM, Yadav V, Irodi A, Mani S, Varghese AM. IgG4-related disease with sinonasal involvement: A case series. Indian J Radiol Imaging. 2014;24:117-20. [CrossRef]

10. Suzuki M, Mizumachi T, Morita S, Kubota K, lizuka K. A case of immunoglobulin 4-related disease with bilateral mass-forming lesions in the nasolacrimal ducts. J Clin Rheumatol. 2011;17:207-10. [CrossRef]

11. Alt JA, Whitaker GT, Allan RW, Vaysberg M. Locally destructive skull base lesion: IgG4-related sclerosing disease. Allergy Rhinol (Providence). 2012;3:e41-5. [CrossRef]

12. Sasaki T, Takahashi K, Mineta $M$, Fujita T, Aburano T. Immunoglobulin G4 - Related sclerosing disease mimicking invasive tumor in the nasal cavity and paranasal sinuses. AJNR Am J Neuroradiol. 2012;33:e1920. [CrossRef]

13. Lindau RH, Su YB, Kobayashi R, Smith RB. Immunoglobulin G4-related sclerosing disease of the paranasal sinus. Head Neck. 2013;35:E321-4. [CrossRef]

14. Cain RB, Colby TV, Balan V, Patel NP, Lal, D. Perplexing lesions of the sinonasal cavity and skull base: IgG4related and similar inflammatory diseases. Otolaryngol Head Neck Surg. 2014;151:496-502. [CrossRef]

15. Morris C, Ng T, Kevin P, Singh N. Immunoglobulin G4 related disease isolated to the nasal cavity: a rare cause of nasal obstruction. J Laryngol Otol. 2015;129:S57-9. [CrossRef]

16. Kurien R, Babu TR, Rupa V. Unusual cause of maxillary sinus mass with proptosis. BMJ Case Rep. 2015;2015:bcr2015210627. [CrossRef] 
17. Kojima M, Nakazato $Y$, Hirabayashi K, Masawa $N$, Nakamura N. IgG4-related plasma cell granuloma of the maxillary sinus: A report of 2 cases. Ear Nose Throat J. 2015;94:E17-9. PMID: 26401675.

18. Vandjelovic ND, Humphreys IM. Immunoglobulin G4-related sclerosing disease of the paranasal sinuses: A case report and literature review. Allergy Rhinol (Providence). 2016;7:85-9. [CrossRef]

19. Chen, BN. IgG4-related disease presenting with destructive sinonasal lesion mimicking malignancy. Eur Arch Otorhinolaryngol. 2016;273:4027-9. [CrossRef]

20. Gontarz M, Wyszynska-Pawelec G, Zapała J, Gałazka K, Tomaszewska RA, Lazar A. IgG4-related disease in the head and neck region: report of two cases and review of the literature. Pol J Pathol. 2016;67:370-5. [CrossRef]

21. Bashyam A, Nagala S, Tahir F, Mirza S. Immunoglobulin G4-related disease of the paranasal sinuses. BMJ Case Rep. 2018;2018:bcr-2018-224472. [CrossRef] 